\title{
SIFAT FISIKOKIMIA HAND AND BODY CREAM DENGAN PEMANFAATAN EKSTRAK ETANOL BUNGA GEMITIR (Tagetes erecta L.) DAN BUNGA PACAR AIR MERAH (Impatiens balsamina L.) DARI LIMBAH CANANG
}

\author{
Dewa Ayu Ika Paramitha ${ }^{1}$, James Sibarani ${ }^{1,2 *}$, Ni Made Suaniti ${ }^{1,2}$ \\ ${ }^{1}$ Magister Kimia Terapan, Program Pascasarjana, Universitas Udayana, Bali-Indonesia \\ 2Jurusan Kimia, Fakultas Matematika dan Ilmu Pengetahuan Alam, Universitas Udayana, Bali- \\ Indonesia \\ *james_sibarani@unud.ac.id
}

\begin{abstract}
ABSTRAK: Pada penelitian ini dilakukan pengembangan formula sediaan hand and body cream dengan memanfaatkan sumber antioksidan yang dimiliki oleh dua jenis ekstrak etanol yaitu ekstrak bunga pacar air merah (Impatiens balsamina L.) dan bunga gemitir (Tagetes erecta L.) dengan taraf perlakuan sebesar 1\% dari masing-masing ekstrak (FPM dan FG) dan campuran $0,5 \%$ ekstrak pacar air merah dan 0,5\% ekstrak gemitir (FCPMG). Pengujian terhadap produk dilakukan pada sifat fisikokimia meliputi $\mathrm{pH}$, viskositas, aktivitas antioksidan, angka lempeng total mikroba, dan ukuran partikel. Berdasarkan hasil pengujian produk hand and body cream yang dihasilkan memiliki antioksidan yang cukup tinggi sebagai produk perawatan tubuh dengan penambahan $1 \%$ ekstrak etanol pacar air merah, gemitir dan campuran dari kedua ekstrak etanol. Kualitas produk hand and body cream yang dihasilkan baik dan memenuhi standar mutu SNI dari aspek nilai $\mathrm{pH}$, viskositas, dan nilai ALT. Warna yang dihasilkan mulai dari warna kuning kemerahan sampai dengan warna kuning, dan partikel yang dimiliki oleh produk adalah nanopartikel dengan sistem polidispersi.
\end{abstract}

Kata kunci: Hand and body cream, Bunga Pacar Air Merah, Bunga Gemitir, Sifat Fisikokimia

\begin{abstract}
Formulations of hand and body creams using ethanol extracts of flowers of red Impatiens balsamina L. And Tagetes erecta L. As antioxidant sources have been developed. One percent of extracts (FPM and FG) and the mixture of $0.5 \%$ each extracts (FCPMG) were added to the basic formula. The analysis of physicochemical properties of the products was conducted including $\mathrm{pH}$, viscosity, antioxidant activity, the size of the particles, and total microbial plate numbers. Based on the results, the quality of the hand and body creams meet the national standard of Indonesia (SNI) regarding to $\mathrm{pH}$, viscosity, and the total microbial numbers. The colours of the hand and body creams resulted are reddish yellow to yellow with polydispersion nanoparticles.
\end{abstract}

Keywords: Hand and body creams, ethanol extracts, Tagetes erecta L., Impatiens balsamina L., 


\section{PENDAHULUAN}

Setiap bagian dari tanaman baik itu batang, daun, bunga, buah maupun biji memiliki metabolit sekunder yang secara alami dihasilkan oleh setiap tanaman untuk melindungi diri atau mempertahankan hidup pada lingkungan tertentu. Begitu pula pada bunga-bunga yang digunakan pada canang. Berdasarkan beberapa penelitian menyebutkan bahwa bunga-bunga tersebut memiliki metabolit sekunder yang mampu memberikan berbagai manfaat. Pada penelitian yang telah dilakukan oleh Nalavothula et al. [1] menyebutkan bahwa daun pacar air (Impatiens balsamina L.) memiliki aktivitas antikanker, dan Shivakumara et al. [2] telah melakukan penelitian terhadap biji pacar air yang terbukti adanya flavonoid, alkaloid, terpenoid dan tanin yang berfungsi sebagai antioksidan, antiinflamasi dan antidiabetes.

Bunga pacar air dan bunga gemitir adalah salah satu bunga yang sangat dibutuhkan oleh masyarakat Bali khususnya oleh umat Hindu di Bali. Bali merupakan salah satu pulau di Indonesia yang dijuluki sebagai pulau Seribu Pura.Bali memiliki banyak pura karena mayoritas masyarakat di Bali merupakan penganut agama Hindu.Budaya masyarakat di Bali, menghaturkan sesajen berupa canang sebagai prasarana dalam melaksanakan upacara agama ataupun hari besar. Canang dibuat dari janur yang dibentuk sedemikian rupa dan dihiasi dengan berbagai macam bunga seperti bunga pacar air berwarna merah dan merah muda, bunga gemitir, pandan wangi dan lain-lain. Biasanya bunga-bunga ini dibuang begitu saja setelah digunakan bahkan dibiarkan hingga mengering.

Hand and body cream adalah produk perawatan tubuh yang biasa digunakan untuk melembabkan dan melindungi kulit dari pengaruh lingkungan. Hand and body cream yang banyak disukai adalah produk krim yang berbentuk O/W (minyak dalam air). Krim berbentuk $\mathrm{O} / \mathrm{W}$ adalah emulsi minyak dalam air yang penampakannya menyerupai lotion yang mengandung fase minyak dan fase humektan yang lebih banyak dari lotion, yaitu $15-40 \%$ fase minyak, 5-15\% humektan dan sisanya adalah fase air. Cream berbentuk O/W biasanya memiliki karakteristik yang mudah diserap kulit setelah digosokkan, tidak lengket di kulit, mudah mengalir dan mudah dipompa [3].

Uji pendahuluan yang telah dilakukan, ditemukan bahwa aktivitas antioksidan dari ekstrak etanol bunga pacar air merah, bunga pacar air merah muda, bunga gemitir, dan pandan wangi dengan konsentrasi 1000 ppm masing-masing adalah $92,26 \% ; 82,42 \% ; 93,67 \% ; 80,42 \%$. Dari hasil tersebut menunjukkan bahwa masing-masing bunga memiliki aktivitas antioksidan yang tinggi. Oleh karena itu dipilih dua jenis bunga dari limbah canang yang memiliki aktivitas terbaik yaitu bunga pacar air merah dan bunga gemitir yang selanjutnya akan digunakan dalam formulasi hand and body cream yang mampu melindungi kulit dari luar.

Berdasarkan uraian tersebut, perlu dirancang komposisi ekstrak etanol yang akan dikombinasikan ke dalam formulasi hand and body cream. Tujuan penelitian ini adalah pengembangan formula sediaan hand and body cream dengan memanfaatkan sumber antioksidan yang dimiliki oleh dua jenis ekstrak etanol yaitu ekstrak bunga pacar air merah dan bunga gemitir dengan taraf perlakuan sebesar $1 \%$ dari masing-masing ekstrak dan campuran $0,5 \%$ ekstrak pacar air merah dengan $0,5 \%$ ekstrak gemitir. Kajian dari penelitian ini adalah mengenai aplikasi jenis ekstrak bunga dari limbah canang dan perbandingan taraf perlakuan pada produk hand and body cream sangat penting dilakukan untuk melihat karakteristik fisikokimia produk hand and body cream yang dikembangkan.

\section{PERCOBAAN}

\section{Bahan Penelitian}


Bahan yang digunakan dalam penelitian ini adalah etanol 96\% (PT. Brataco), metanol p.a (Merck), ekstrak etanol bunga pacar merah dan gemitir dari limbah canang, 2,2-Diphenyl-1-picrylhydrazyl (DPPH; Sigma-Aldrich), minyak kelapa (homemade), dimetikon (Dow Corning), tween 80 (PT. Brataco), setil alkohol (PT. Brataco), propilen glikol (PT. Brataco), alantoin (PT. Brataco), metil paraben (PT. Brataco), propil paraben (PT. Brataco), titanium dioksida (PT. Brataco), gliserol (PT. Brataco), sorbitol (PT. Brataco), butil hidroksi toluena (BHT) (PT. Brataco).

\section{Alat Penelitian}

Alat yang digunakan dalam penelitian ini adalah Spektrofotometer UV-Vis (UV1800 Shimadzu double beam), Particle Size Analyser (PSA Horiba ZS-100), pH-meter (ditech pH 600), neraca analitik (Shimadzu AUW220D), kromameter (Brookfield), kromameter (Accuprobe HH06).

\section{Persiapan Sampel}

Bunga pacar merah dan bunga gemitir dikumpulkan dari limbah canang. Bunga yang telah dikumpulkan masing-masing dimaserasi dengan etanol $96 \%$ hingga semua terendam sempurna selama 24 jam. Selanjutnya campuran disaring sehingga diperoleh ekstrak dan residu, setelah itu residu direndam kembali dengan etanol sampai 3 kali hingga tidak berwarna. Selanjutnya ekstrak digabung dan dilakukan pemekatan dengan alat rotary vakum evaporator sehingga diperoleh ekstrak kental. Ekstrak kental ini yang akan digunakan dalam formulasi produk hand and body cream.

\section{Penyusunan Formulasi Dasar Hand and Body Cream}

Penyusunan formula dilakukan dengan memperkirakan konsentrasi bahan-bahan yang digunakan melalui studi literatur seperti yang telah dilakukan oleh Rahmanto [4]. Fase minyak pada umumnya menggunakan minyak mineral atau ester dari suatu asam lemak, misalnya isopropil palmitat atau isopropil miristat diganti dengan penggunaan langsung minyak nabati. Pada penyusunan formulasi digunakan minyak kelapa sebagai pensuplai minyak pada sediaan hand and body cream yang dikembangkan. Bahan lainnya yang digunakan meliputi setil alkohol dan asam stearat sebagai penstabil dan pembentuk konsistensi kekentalan pada krim, emulsifier untuk emulsi $O / W$, dimetikon sebagai anti busa dan pelembut, titanium dioksida sebagai pigmen putih, anti UV dan pemberi kesan kering pada sediaan cream, alantoin untuk anti iritasi, metil paraben dan propil paraben untuk anti mikroba, BHT untuk antioksidan, gliserol, propilen glikol dan sorbitol sebagai humektan, serta air sebagai fase pendispersi.

Proses pembuatan sediaan cream tipe $O / W$ diawali dengan pencampuran humektan dan bahan yang larut air ke dalam air murni dan dipanaskan hingga suhu $65-70^{\circ} \mathrm{C}$ (sediaan fase air). Di tempat lain, bahan yang tergolong ke dalam fase minyak dilarutkan dan dicampur terpisah pada suhu $65-70^{\circ} \mathrm{C}$ (sediaan fase minyak). Setelah semua bahan bercampur 3actor3y, fase minyak dituangkan sedikit demi sedikit ke dalam fase air sambil diaduk untuk mempersiapkan proses emulsifikasi. Emulsi yang sempurna dibentuk dengan bantuan alat emulsifikasi seperti homomixer atau homogenizer.Pengadukan dengan mixer dilakukan selama 10 menit pada kecepatan tinggi.Setelah terbentuk emulsi yang sempurna, pengadukan tetap dilakukan dengan kecepatan rendah hingga suhu sediaan turun dan membentuk konsistensi krim.

\section{Pembuatan Produk Hand and Body Cream}

Pembuatan produk hand and body cream dilakukan dengan memvariasikan komposisi ekstrak kental bunga yang memiliki aktivitas antioksidan tertinggi. Formula dasar produk hand and body cream yang telah dibuat dengan minyak kelapa selanjutnya disubstitusi dengan ekstrak kental bunga. Rancangan formula 
Tabel 1. Komposisi Bahan Penyusun Hand and Body Cream

\begin{tabular}{lccc}
\hline \multirow{2}{*}{\multicolumn{1}{c}{ Bahan }} & \multicolumn{3}{c}{ Komposisi } \\
\cline { 2 - 4 } & FPM & FCPMG & FC \\
\hline Minyak kelapa & $10,0 \%$ & $10,0 \%$ & $10,0 \%$ \\
Setil alkohol & $4,0 \%$ & $4,0 \%$ & $4,0 \%$ \\
Asam stearat & $5,0 \%$ & $5,0 \%$ & $5,0 \%$ \\
Tween 80 & $5,0 \%$ & $5,0 \%$ & $5,0 \%$ \\
Dimetikon & $0,5 \%$ & $0,5 \%$ & $0,5 \%$ \\
$\mathrm{TiO}_{2}$ & $1,0 \%$ & $1,0 \%$ & $1,0 \%$ \\
$\mathrm{Alantoin}_{\text {Metilparaben }}$ & $0,5 \%$ & $0,5 \%$ & $0,5 \%$ \\
Propilparaben & $0,1 \%$ & $0,1 \%$ & $0,1 \%$ \\
BHT & $0,1 \%$ & $0,1 \%$ & $0,1 \%$ \\
Gliserol & $0,1 \%$ & $0,1 \%$ & $0,1 \%$ \\
Propilen glikol & $3,0 \%$ & $3,0 \%$ & $3,0 \%$ \\
Sorbitol & $2,0 \%$ & $2,0 \%$ & $2,0 \%$ \\
Aquades & $5,0 \%$ & $5,0 \%$ & $5,0 \%$ \\
Ekstrak bunga pacar merah & $62,7 \%$ & $62,7 \%$ & $62,7 \%$ \\
Ekstrak bunga gemitir & $1,0 \%$ & $0,5 \%$ & $0 \%$ \\
\hline
\end{tabular}

yang diteliti lebih lanjut adalah dengan penetapan kadar minyak sebesar $10 \%$. Fokus penelitian ini adalah pada faktor tunggal dan 3 taraf perlakuan dari ekstrak bunga yang memiliki antioksidan terbaik yaitu $1 \%$ dari masing-masing ekstrak bunga pacar merah dan bunga gemitir, serta campuran dari $0,5 \%$ ekstrak bunga pacar air merah dan $0,5 \%$ ekstrak bunga gemitir. Ekstrak bunga yang digunakan adalah ekstrak dari bunga segar dari limbah canang. Ekstrak akan disubstitusikan ke dalam fase air, sehingga komposisi air (aquades) dan ekstrak berdasarkan taraf perlakuan seperti pada Tabel 1.

\section{Pengujian Hasil Hand and Body Cream}

Pengujian hasil Hand and Body Cream dilakukan dengan menentukan mikrobiologi (penentuan lempeng total mikroba), penentuan nilai $\mathrm{pH}$, ukuran partikel, viskositas, dan warna. Setiap pengujian akan dilakukan pengulangan sebanyak tiga kali.

\section{Penentuan Angka Lempeng Total (ALT)}

Larutan sempel dibuat dengan faktor pengenceran sebesar $10^{-1}, 10^{-2}, 10^{-3}, 10^{-4} .1$ gram sampel ditambahkan larutan steril $\mathrm{NaCl}$ 0,85\% hingga volume menjadi $10 \mathrm{~mL}$ dan diaduk sampai homogen, sehingga didapat sampel dengan faktor pengenceran $10^{-1}$. Dibuat pengenceran $10^{-2}$ dengan dilarutkan $1 \mathrm{~mL}$ sampel dari pengenceran $10^{-1}$ dengan larutan steril $\mathrm{NaCl} 0,85 \%$ hingga volume menjadi $10 \mathrm{~mL}$. Cara yang sama dibuat seri pengenceran $10^{-3}, 10^{-4}, 10^{-}$ 5 . Kemudian dilakukan inokulasi sampel pada media. Sebanyak $1 \mathrm{~mL}$ larutan sampel yang telah diencerkan dimasukkan kedalam cawan petri.Kemudian ke dalam cawan tersebut dituangkan nutrient agar steril sebanyak 12-15 mL.Agar suspensi tercampur homogen, cawan petri diputar membentuk angka delapan.Selanjutnya dibiarkan sampai media padat dan diinkubasi dengan suhu $37^{\circ} \mathrm{C}$ selama semalam.Media yang telah diinkubasikan selama semalam dikeluarkan. Perhitungan Angka Lempeng Total Bakteri (ALTB) 
dilakukan dengan cara menghitung koloni yang berdiameter $0,5-3,0 \mathrm{~mm}$ dengan jumlah koloni antara 30-300 CFU/gram [5].

\section{Penentuan Nilai pH}

Ditimbang 0,1 gram sampel dilarutkan dengan akuades hingga $10 \mathrm{~mL}$. Nilai $\mathrm{pH}$ diukur dengan menggunakan $\mathrm{pH}$-meter yang telah dikalibrasi.

\section{Viskositas}

Uji viskositas dilakukan dengan metode Brookfield yaitu menggunakan Brookfield DV III Programmable Rheometer. Sampel dimasukkan ke dalam wadah/gelas piala kemudian diukur viskositasnya dengan viskometer (spindle 1) dengan kecepatan $15 \mathrm{rpm}$, indikator suhu dicelupkan pada sampel untuk mengetahui suhu pengukuran sampel. Viskositasnya (cP) adalah hasil angka pengukuran yang tertera langsung pada layar display alat Brookfield. Hasil pengukuran dianggap valid hanya untuk pengukuran dengan nilai torsi di atas $10 \%$.

\section{Warna (Atribut Kecerahan)}

Pengukuran warna sampel produk dilakukan dengan menggunakan alat Chromameter Minolta CR 300, dengan penentuan L, a, b. Sampel diratakan pada tempat sampel yang sesuai. Selanjutnya sampel uji diukur nilai warna dengan memasukkan detektor kedalam wadah sampel. Hasil nilai warna dalam L, a, b tercatat dalam bentuk print out.

\section{Ukuran Partikel}

Analisis ukuran partikel pada penelitian ini adalah penetapan distribusi ukuran partikel dan indeks polidispersitas. Penetapan distribusi ukuran partikel, dan indeks polidispersitas dilakukan dengan mendispersikan sampel hand and body cream dengan aquades pada suhu kamar $\left( \pm 25^{\circ} \mathrm{C}\right)$ dengan perbandingan $1 / 100(\mathrm{~b} / \mathrm{v})$ selanjutnya diukur dengan menggunakan Particle Size Analyzer (PSA).

\section{Stabilitas emulsi}

Pengamatan stabilitas emulsi dilakukan pada suhu ruangan dalam waktu 14 minggu. Parameter yang diuji pada stabilitas emulsi adalah nilai $\mathrm{pH}$, viskositas dan angka lempeng total (ALT) mikroba.

\section{HASIL DAN PEMBAHASAN}

\section{Formulasi dan Pembuatan Hand and Body Cream}

Percobaan dilakukan sesuai dengan formulasi yang telah ditetapkan. Percobaan menggunakan minyak kelapa $10 \%$ merujuk pada penelitian yang dilakukan oleh Rahmanto [4]. Penggunaan minyak kelapa $10 \%$ karena produk akhir yang diperoleh menunjukkan karakteristik yang lebih baik, aplikasi produk krim pada kulit terasa normal seperti produk krim pada umumnya dan emulsi krim terlihat stabil dan homogen. Dari hasil percobaan ini maka ditetapkan konsentrasi dan jenis ekstrak yang digunakan sebagai rancangan percobaan aplikasi pemanfaatan ekstrak etanol bunga pacar air merah dan gemitir sebagai pensubstitusi adalah $1 \%$ ekstrak etanol bunga pacar merah (FPM), 1\% ekstrak etanol bunga gemitir (FG) dan $1 \%$ dari campuran ekstrak etanol bunga pacar air merah $(0,5 \%)$ dan ekstrak etanol bunga gemitir (0,5\%) (FCPMG). Hasil jadi produk hand and body cream ditampilkan pada Gambar 1.

\section{FPM \\ FG \\ FCPMG}

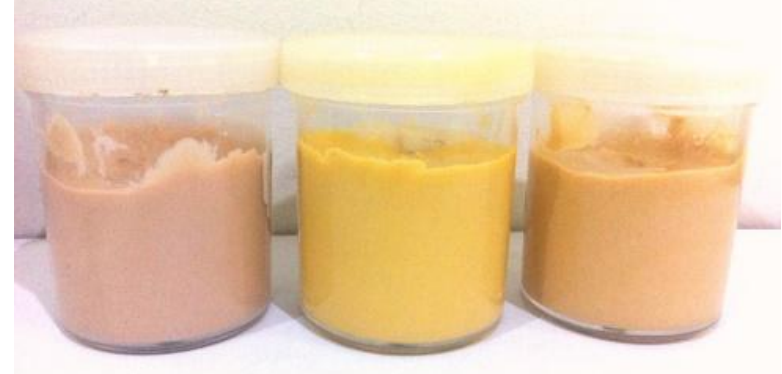

Gambar 1. Produk hand and body cream 
Tabel 2. Hasil Analisis Fisikokimia Produk Hand and Body Cream

\begin{tabular}{|c|c|c|c|c|c|}
\hline \multirow{2}{*}{ Kriteria Uji } & \multicolumn{3}{|c|}{ Sampel } & \multirow{2}{*}{$\boldsymbol{P}$} & \multirow{2}{*}{ SNI } \\
\hline & FPM & FG & FCPMG & & \\
\hline Penampakan & Homogen & Homogen & Homogen & & Homogen \\
\hline $\mathrm{pH}$ & $5,163^{\mathrm{ab}}$ & $5,253^{\mathrm{a}}$ & $4,997^{\mathrm{b}}$ & $0,039 *$ & $4,5-8,0$ \\
\hline Viskositas (cP) & $7.783^{\mathrm{c}}$ & $10.200^{\mathrm{a}}$ & $9.233^{\mathrm{b}}$ & $0,000 *$ & $2.000-50.000$ \\
\hline TPC (koloni/g) & Negatif & Negatif & Negatif & & Maks. $10^{2}$ \\
\hline Aktivitas & $86,71^{\mathrm{c}}$ & $90,15^{\mathrm{b}}$ & $87,97^{\mathrm{a}}$ & $0,000 *$ & - \\
\hline \multicolumn{6}{|l|}{ Antioksidan (\%) } \\
\hline Warna : L & $27,65^{\mathrm{b}}$ & $30,32^{\mathrm{a}}$ & $26,68^{b}$ & $0,015 *$ & - \\
\hline $\mathrm{C}$ & $17,43^{\mathrm{b}}$ & $24,73^{\mathrm{a}}$ & $25,48^{\mathrm{a}}$ & $0,000 *$ & - \\
\hline$h^{\circ}$ & $84,80^{\mathrm{c}}$ & $111,27^{\mathrm{a}}$ & $92,14^{\mathrm{b}}$ & $0,000 *$ & - \\
\hline Ukuran partikel (nm) & $785,3^{\mathrm{a}}$ & $1.235,77^{\mathrm{a}}$ & $784,53^{\mathrm{a}}$ & $0,359 * *$ & - \\
\hline Indeks Polidispersitas & $0,978^{\mathrm{ab}}$ & $0,857^{\mathrm{b}}$ & $1,213^{\mathrm{a}}$ & $0,098 * *$ & - \\
\hline
\end{tabular}

\section{Sifat Fisikokimia Hand and Body Cream}

Hasil analisis sifat fisikokimia dari sampel dalam penelitian ini dapat diterima secara umum untuk menggambarkan bentuk produk sediaan krim. Data hasil pengujian produk ditampilkan lengkap dengan SNI yang digunakan sebagai perbandingan pada Tabel 2 .

\section{pH}

Nilai $\mathrm{pH}$ suatu produk perawatan kulit harus disesuaikan dengan $\mathrm{pH}$ penerimaan kulit. Kulit dapat beradaptasi dengan baik ketika berinteraksi dengan bahan yang memiliki nilai $\mathrm{pH}$ sekitar 4,5-8,0 karena nilai $\mathrm{pH}$ yang dimiliki oleh kulit adalah sekitar 5,0-6,5. Hasil pengukuran nilai $\mathrm{pH}$ dari produk hand and body cream yang dikembangkan dengan penambahan ekstrak etanol bunga pacar air merah dan ekstrak etanol bunga gemitir dari limbah canang menunjukkan bahwa sudah memenuhi syarat SNI. Hubungan nilai $\mathrm{pH}$ dari formulasi dengan penambahan ekstrak etanol bunga pacar air merah dan gemitir disajikan dalam Gambar 2.

Hasil analisis ragam pada tingkat kepercayaan $95 \%$ menunjukkan bahwa nilai $\mathrm{pH}$ dari produk FPM lebih rendah dari produk FG, namun tidak ada perbedaan yang nyata.Begitu juga dengan produk FCPMG tidak berbeda nyata dengan produk FPM walaupun nilai $\mathrm{pH}$ produk
FCPMG lebih rendah.Namun, nilai $\mathrm{pH}$ dari produk FCPMG memiliki perbedaan yang nyata dengan produk FG. Nilai rataan $\mathrm{pH}$ tertinggi yang diperoleh adalah 5,25 yaitu produk hand and body cream dengan penambahan $1 \%$ ekstrak etanol bunga gemitir (FG). Kemungkinan interaksi dari ekstrak etanol bunga gemitir dan pacar air merah jika dicampur akan menurunkan nilai $\mathrm{pH}$ dari produk. Nilai $\mathrm{pH}$ akhir produk juga sangat dipengaruhi oleh $\mathrm{pH}$ dari bahan-bahan penyusun yang digunakan. Seperti minyak dan bahan-bahan yang larut dalam minyak berada pada rentang $\mathrm{pH}$ asam sehingga akan menurunkan nilai $\mathrm{pH}$ akhir dari produk.

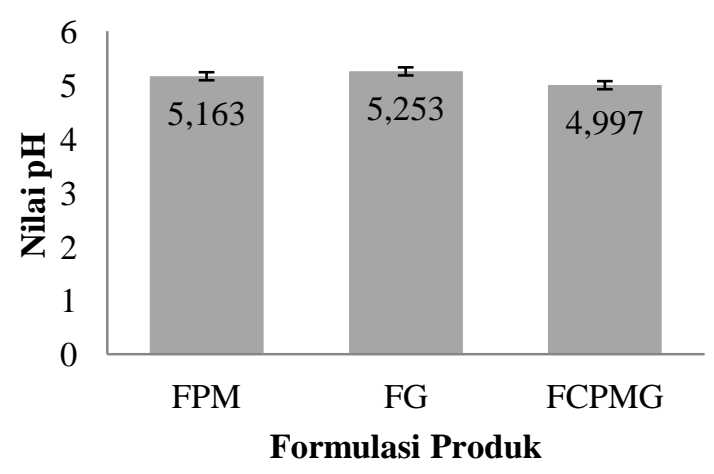

Gambar 2. Nilai $\mathrm{pH}$ produk hand and body cream 


\section{Viskositas}

Pengaruh penambahan ekstrak pada produk hand and body cream terhadap viskositas dapat dilihat pada Gambar 3 dimana viskositas produk berada pada rentang 7783-10200 cP. Hasil analisis viskositas menunjukkan bahwa nilai viskositas produk FG lebih besar dibandingkan dengan produk FPM dan FCPMG.. Analisis ragam menunjukkan adanya pengaruh penambahan ekstrak dengan nilai viskositas yang dihasilkan pada tingkat kepercayaan 95\%. Rataan tertinggi viskositas adalah pada produk dengan penambahan $1 \%$ ekstrak etanol bunga gemitir (FG) yaitu sebesar $10200 \mathrm{cP}$, sedangkan rataan nilai viskositas terendah dimiliki oleh produk dengan penambahan $1 \%$ ekstrak etanol bunga pacar air merah (FPM) yaitu sebesar 7783 cP. Nilai viskositas produk hand and body cream dipengaruhi oleh ekstrak yang digunakan. Penentu kekentalan dan pembentuk viskositas pada sediaan krim juga dipengaruhi oleh bahan-bahan penyusun yang digolongkan pada fase minyak seperti asam stearat, setil alkohol dan bahan emulsifier. Bahan-bahan ini merupakan pengganti lemak karena memiliki karakteristik padat pada suhu ruang. Homogenitas emulsi yang paling baik akan mampu mengoptimalkan pengaruh bahanbahan pengental dalam meningkatkan viskositas produk melalui prinsip penyebaran molekulnya yang merata dalam emulsi.

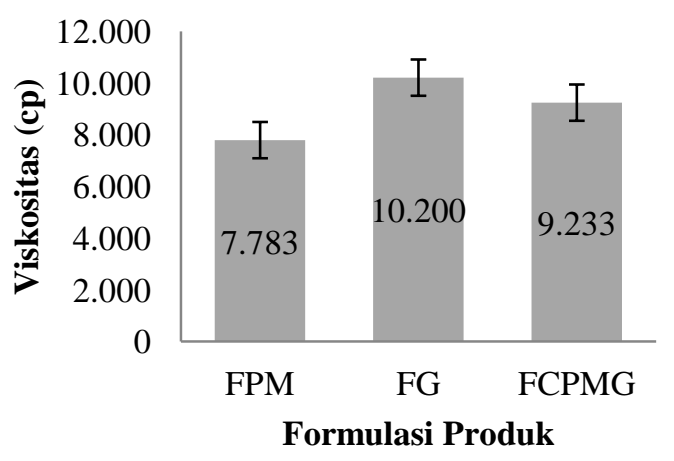

Gambar 3. Viskositas produk hand and body cream
Angka Lempeng Total Mikroba (ALT)

Analisis total mikroba penting dilakukan untuk mengetahui ada tidaknya mikroba dalam produk hand and body cream yang dikerjakan. Analisis ini penting karena kontaminasi dari mikroba dapat menyebab- kan pemisahan, penyusutan berat produk dan timbulnya bau yang tidak sedap. Kerusakan yang terjadi pada produk dapat disebabkan oleh adanya bakteri, ragi ataupun jamur. Karakteristik mikroorganisme yang memiliki kemampuan beradaptasi yang tinggi terhadap lingkungan menyebabkan beragam komponen organik alami menjadi sangat mudah rusak atau terdegradasi.

Hasil pengujian ALT pada produk dalam penelitian ini menunjukkan hasil yang baik, yaitu pada pengenceran $10^{-1}$ tidak ditemukan adanya mikroorganisme yang tumbuh pada media agar yang ditambahkan sampel, sehingga tidak perlu dilakukan pengenceran kembali. Hasil ini menunjukkan bahwa proses aseptis produk telah tercapai dan juga penambahan kandungan senyawa aktif yang mampu sebagai anti mikroba dan mampu menghambat pertumbuhan mikroorganisme. Hal ini juga mendukung bahwa ekstrak etanol bunga pacar air merah dan ekstrak etanol bunga gemitir yang memiliki potensi sebagai antibakteri. Hasil analisis total mikroba dapat dilihat pada Gambar 4.

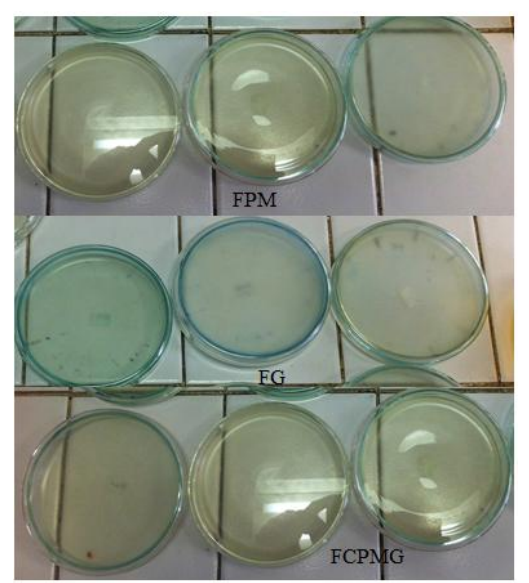

Gambar 4. Uji angka lempeng total (ALT) produk hand and body cream 


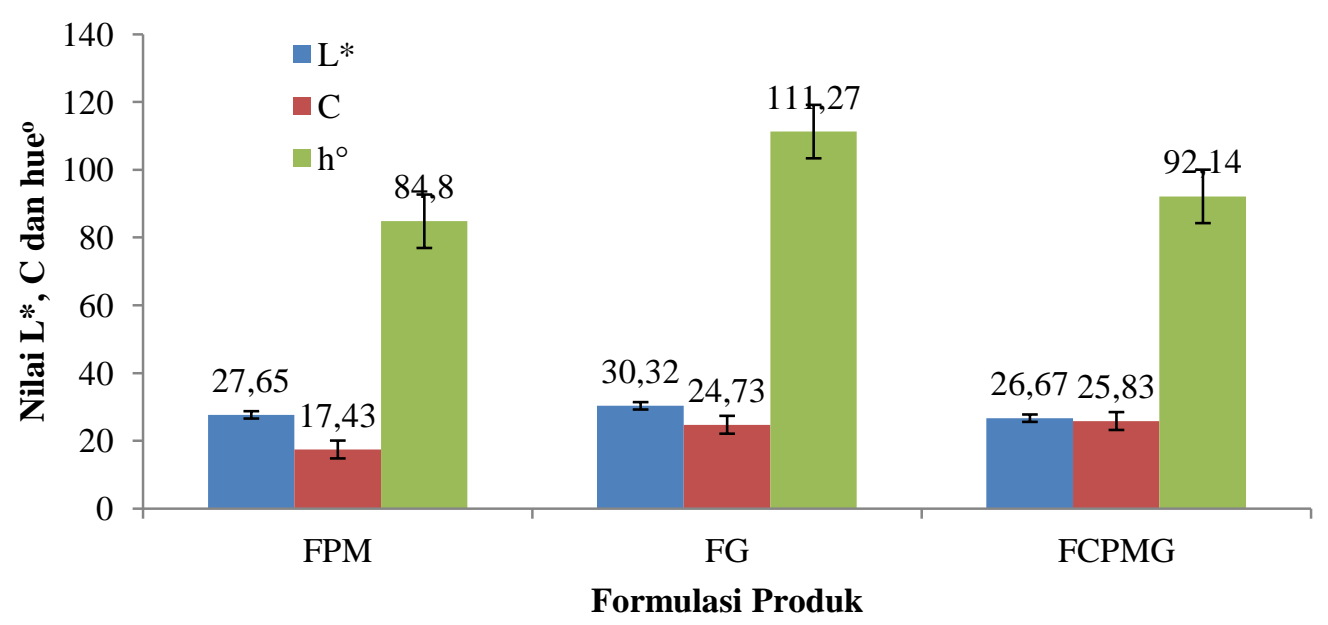

Gambar 5. Nilai L (Lightness), C (kroma), dan $\mathrm{h}^{\circ}$ (hue) produk hand and body cream

\section{Warna}

Hasil analisis warna produk menunjukkan bahwa dengan penambahan $1 \%$ ekstrak etanol bunga gemitir (FG) memberikan tingkat kecerahan (lightness) yang lebih tinggi yaitu dengan nilai $L$ sebesar 30,32 (Gambar 5). Perubahan daerah kisaran warna ditentukan oleh nilai Hue $\left(h^{\circ}\right)$ dan intensitas warna (C). Berdasarkan nilai $\mathrm{h}^{\circ}$, produk hand and body cream pada penelitian ini memiliki kisaran warna dari kuning kemerahan $\left(54^{\circ}\right.$ $90^{\circ}$ ) hingga kuning $\left(90^{\circ}-126^{\circ}\right.$ ) yaitu $84,80^{\circ}$ (kuning kemerahan) untuk produk FPM, $111,27^{\circ}$ (kuning) untuk produk FG, dan 92,14 ${ }^{\circ}$ (kuning) untuk produk FCPMG. Berdasarkan intensitas warna (nilai C) yang dihasilkan, produk FCPMG memiliki nilai $\mathrm{C}$ yang paling tinggi yaitu 25,14, dan produk FPM memiliki nilai $\mathrm{C}$ yang rendah yaitu 17,43. Hasil analisis ragam menunjukkan bahwa penambahan ekstrak etanol berpengaruh nyata terhadap tingkat kecerahan (L) nilai kroma (C) dan derajat hue $\left(h^{\circ}\right)$ dengan $p<0,05$.

Hasil uji lanjut Duncan untuk nilai tingkat kecerahan menunjukkan bahwa pada produk FPM dan FCPMG tidak terlihat adanya perbedaan yang nyata. Produk FG memiliki tingkat kecerahan yang paling tinggi dan berbeda nyata dengan produk FPM dan FCPMG. Sebaliknya pada nilai kroma, produk FG dan FCPMG menujukkan tidak adanya perbedaan yang nyata, sedangkan FPM memiliki nilai kroma terendah dan berbeda nyata dengan produk FG dan FCPMG. Selanjutnya pada derajat hue $\left(h^{\circ}\right)$ dari ketiga produk memiliki pengaruh yang berbeda nyata.

Produk hand and body cream yang dibuat secara keseluruhan memilliki karakteristik warna yang baik. Tingkat kecerahan (L) warna FPM dan FG menurun terhadap FCPMG, namun tingkat kecerahan FPM dan FCPMG tidak menunjukkan adanya perbedaan yang nyata. Hasil ini menujukkan bahwa produk dengan penambahan ekstrak etanol bunga gemitir memiliki transparansi yang lebih baik dari ekstrak etanol bunga pacar air merah dan campuran dari ekstrak etanol bunga pacar air merah dan gemitir, sehingga memiliki efek penurunan kecerahan yang lebih kecil. Nilai kromasitas atau intensitas warna krim berbeda nyata, namun seluruhnya berada tidak jauh dari pusat warna sehingga warna sediaan sesungguhnya yang dimiliki oleh sediaan adalah mendekati abu-abu. Warna yang tampak pada krim saat diamati secara visual terjadi karena adanya efek pembiasan cahaya oleh globula-globula emulsi dan warna yang dimiliki oleh ekstrak itu sendiri.Secara statistik adanya perbedaan yang nyata dari produk FPM 
Tabel 3. Ukuran Partikel dan Indeks Polidispersi

\begin{tabular}{lcccc}
\hline \multicolumn{1}{c}{ Parameter } & FPM & FG & FCPMG & $\boldsymbol{P}$ \\
\hline Ukuran Partikel (nm) & $785,33^{\mathrm{a}}$ & $1235,77^{\mathrm{a}}$ & $784,53^{\mathrm{a}}$ & $0,359^{* *}$ \\
Indeks Polidispersi & $0,978^{\mathrm{ab}}$ & $0,857^{\mathrm{a}}$ & $1,213^{\mathrm{b}}$ & $0,098^{* *}$ \\
\hline
\end{tabular}

Keterangan : ** tidak berbeda bermakna $(p>0,05)$

Nilai rerata yang diikuti dengan huruf yang tidak sama berarti berbeda secara bermakna

dengan FG dan FCPMG, namun produk FG dan FCPMG tidak memiliki perbedaan nyata yang kemungkinan disebabkan interaksi warna yang dimiliki oleh ekstrak etanol bunga gemitir lebih banyak dibandingkan dengan ekstrak etanol bunga pacar air merah sehingga pada campurannya memiliki intensitas yang tidak berbeda nyata dengan ekstrak etanol bunga gemitir. Pada derajat hue $\left(h^{\circ}\right)$, adanya perbedaan yang nyata dialami oleh produk baik itu dengan penambahan masing-masing ekstrak atauppun dengan campuran. Walaupun berbeda nyata, krim dengan penambahan $1 \%$ ekstrak etanol bunga gemitir (FG) dan $1 \%$ campuran (FCPMG) memiliki golongan warna yang sama yaitu warna kuning. Sedangkan krim dengan penambahan $1 \%$ ekstrak etanol bunga pacar air merah (FPM) memiliki golongan warna kuning kemerahan.

\section{Ukuran Partikel dan Globula}

Analisis ukuran partikel yang dilakukan dalam penelitian ini meliputi penetapan distribusi ukuran partikel dan indeks polidispersitas. Penetapan distribusi ukuran partikel dan indeks polidispersitas dilakukan dengan cara mendispersikan produk hand and body cream dengan akuades pada suhu $25^{\circ} \mathrm{C}$ dengan menggunakan alat Particle Size Analyzer (PSA) Horiba SZ-100.

Hasil analisis menunjukkan bahwa produk yang dikembangkan menghasilkan ukuran partikel dalam kisaran nanopartikel (1-1000 nm). Produk krim dengan penambahan ekstrak etanol bunga pacar air merah (FPM) dan campuran ekstrak (FCPMG) memiliki ukuran partikel yang tidak jauh berbeda yaitu secara berturut- turut sebesar 785,33 $\mathrm{nm}$ dan 784,58 nm. Hasil analisis diperlihatkan secara lengkap pada Tabel 3. Ukuran partikel dari produk hand and body cream dengan penambahan ekstrak etanol bunga pacar air merah dan campuran ekstrak masih berada dibawah $1000 \mathrm{~nm}$, maka dengan demikian produk krim yang dikembangkan memiliki ukuran nanopartikel.

Nilai indeks polidispersitas pada produk krim memiliki nilai yang tinggi, yaitu 0,978 untuk produk FPM, 0,857 untuk produk FG, dan 1,213 untuk produk FCPMG. Hasil ini menunjukkan bahwa sistem yang terbentuk dalam produk krim yang dikembangkan adalah sistem polidispersi. Sistem polidispersi memperlihatkan distribusi ukuran partikel yang cenderung lebar yang menandakan sistem suspensi polidispersi yang heterogen. Karena sistem polidispersi memiliki kecenderungan partikel membentuk agregat, maka sistem polidispersi menjadi kurang stabil dibandingkan dengan sistem monodispersi. Agregat tersebut dapat terjadi apabila partikel-partikel yang terdapat dalam sistem polidispersi memiliki potensial zeta permukaan yang mendekati nol. Ukuran partikel yang besar disebakan juga karena proses pengocokan yang tidak cepat sehingga partikel menjadi tidak homogen ini karena keterbatasan alat berupa homogenizer.

Hasil analisis ragam menunjukkan bahwa ukuran partikel produk tidak dipengaruhi oleh ekstrak etanol bunga yang digunakan. Penambahan ekstrak etanol bunga hanya berpengaruh pada indeks polidispersitas (IP). Hasil uji lanjut Duncan untuk indeks polidispersitas menunjukkan bahwa produk FPM tidak berbeda nyata 
Tabel 4. Nilai viskositas, $\mathrm{pH}$, dan angka lempeng total mikroba (ALT) pada hari ke-14

\begin{tabular}{lccc}
\hline \multicolumn{1}{c}{ Pengukuran } & FPM & FG & FCPMG \\
\hline Viskositas (cP) & 7233 & 8117 & 7100 \\
pH & 3,82 & 4,42 & 3,92 \\
ALT $(\mathbf{C F U} / \mathbf{g})$ & $533 \times 10^{1}$ & $493 \times 10^{1}$ & $713 \times 10^{1}$ \\
\hline
\end{tabular}

dengan produk FG dan FCPMG, namun produk FG berbeda nyata dengan produk FCPMG.

Hasil ukuran partikel dan indeks polidispersitas didukung pula oleh pengamatan ukuran globula produk hand and body cream dengan menggunakan mikroskop. Hasil pengamatan menunjukkan bahwa produk hand and body cream yang dihasilkan merupakan tipe emulsi minyak di dalam air $(\mathrm{O} / \mathrm{W})$, yaitu minyak menjadi fase terdispersi dan air sebagai fase pendispersinya.

\section{Stabilitas emulsi}

Pengujian stabilitas emulsi merupakan parameter penting dalam suatu produk emulsi.Tingkat kestabilan emulsi menunjukkan daya tahan suatu produk emulsi terhadap kondisi tertentu dan dalam rentang waktu tertentu. Produk yang tidak stabil akan memiliki kecenderungan cepat rusak sehingga kehilangan fungsi dan manfaatnya serta tidak akan disukai konsumen. Ketidakstabilan ini ditandai dengan mudah terpisahnya partikel-partikel emulsi yang dapat menyebabkan pengumpulan globula, penggabungan, kriming dan pemisahan fase. Kerusakan emulsi diawali ketika dua butiran fase internal saling mendekat dan bergabung membentuk partikel yang lebih besar.Sejumlah tertentu partikel yang mengalami koalesen ini dapat memisahkan kedua fase emulsi secara sempurna.

Pengujian stabilitas pada penelitian ini dilakukan dengan pengujian suhu penyimpanan. Produk hand and body cream disimpan pada suhu $\pm 23^{\circ} \mathrm{C}$ selama 14 hari. Pada hari ke-0 dilakukan pengujian terhadap nilai $\mathrm{pH}$, viskositas, dan ALT. Pengamatan yang sama kembali dilakukan pada hari ke-14 (Tabel 4).

Hasil pengamatan menunjukkan adanya perubahan dengan menurunnya nilai viskositas dan nilai $\mathrm{pH}$, serta meningkatnya jumlah mikroba pada uji ALT. Hasil ini menandakan bahwa adanya ketidakstabilan terhadap produk hand and body cream. Ketidakstabilan terjadi dikarenakan adanya mikroba yang tumbuh, hal ini kemungkinan disebabkan karena sampel ekstrak yang digunakan adalah sampel basah, sehingga kandungan air yang ada pada sampel masih tinggi sehingga kemungkinan adanya pertumbuhan mikroorganisme baik itu bakteri ataupun jamur.

\section{SIMPULAN}

Produk hand and body cream yang dihasilkan memiliki kualitas yang cukup baik dan memenuhi standar mutu SNI dari aspek nilai $\mathrm{pH}$, viskositas, dan nilai angka lempeng total mikroba (ALT).Perbedaan penambahan jenis ektrak etanol bunga berpengaruh nyata terhadap nilai $\mathrm{pH}$, viskositas, tingkat kecerahan (L), intensitas warna $(\mathrm{C})$, derajat hue $\left(\mathrm{h}^{\circ}\right)$, dan indeks polidispersitas, namun tidak berbeda nyata terhadap ukuran partikel. Produk hand and body cream yang dihasilkan tidak dipengaruhi oleh penambahan ekstrak etanol bunga dari limbah canang terhadap nilai sensori pada semua parameter yang diuji.

\section{DAFTAR PUSTAKA}

1. Nalavothula, R., Alwala, J., Nagati, V.B., and Manthurpadigya, P.R. 2014. 
Biosynthesis of silver nanoparticles using Impatiens balsamina leaf extracts and its characterization and cytotoxic studies using human cell lines. International Journal of ChemTech Research. 7 (5): $2460-$ 2468.

2. Shivakumara, Seitjit, W., Naveen, K. R., Swarnava, K., Shivaji, B., and Vedamurthy A.B. 2014.Phytochemical Screening and Biological Activities of Impatiens balsamina L. seeds. International Journal of Fundamental \& Applied Sciences. 3(2): 22 - 26.
3. Williams, D.F., and Schmitt, W.H. 1992. Chemistry and Technology of Cosmetics and Toiletries Industry. London : Blackie Academic and Professional.

4. Rahmanto, A. 2011. Pemanfaatan Minyak Jarak Pagar (Jatropha curcas, Linn.) Sebagai Komponen Sediaan dalam Formulasi Produk Hand and Body Cream.Tesis. Sekolah Pascasarjana Institut Pertanian Bogor.

5. Buckle, KA., Edwards, RA., Fleet GH., Wooton, M. 1987. Ilmu Pangan. Penerjemah Hari Purnomo dan Adiono. Jakarta : Universitas Indonesia Press 